\section{Comparison of the Binding Activities of Chloronicotinyl Insecticides toward the Nicotinic Acetylcholine Receptors from Rats and Houseflies}

\author{
Atsushi OKaZAwa, Yoshiaki NaKagawa, ${ }^{*}$ \\ Miki AKAMATSU, Tamio UENo \\ and Keiichiro NISHIMURA ${ }^{\dagger}$
Graduate School of Agriculture, Kyoto University, Kyoto 606-8502, Japan \\ ${ }^{\dagger}$ Research Institute for Advanced Science and Technology, \\ Osaka Prefecture University, Sakai, Osaka 599-8570, Japan
}

(Received August 11, 1999; Accepted November 4, 1999)

Key words: chloronicotinyl insecticides, imidacloprid, acetamiprid, nitenpyram, binding activity, selectivity.

\section{INTRODUCTION}

Chloronicotinyl insecticides such as imidacloprid, acetamiprid and nitenpyram are a class of novel potent insecticides developed by Japanese and German companies in the late 1980s. These insecticides have the 6-chloro-3-pyridylmethyl moiety as a common structure and the remaining functional groups can be either cyclic or acyclic. This class of compounds is characterized by broad spectra, good systemic properties, low toxicity to mammals and aquatic life, and moderate stability in agricultural fields. ${ }^{1-6)}$

This class of insecticides acts at the nicotinic acetylcholine receptor ( $\mathrm{AAChR}$ ) of insects by selectively perturbing the neuronal signal transduction. ${ }^{7,8)}$ Radiolabelled $\alpha$ bungarotoxin ( $\alpha$-BGTX), which binds antagonistically to acetylcholine binding sites of the $\mathrm{nAChR}$, has been widely used in competitive receptor-binding assays to evaluate the bioactivity of these compounds. ${ }^{7,9-11)}$ Recently, $\left[{ }^{3} \mathrm{H}\right]$ imidacloprid was also used in this receptor-binding assay to clarify the binding mode of this class of insecticides. ${ }^{12-17)}$ A good correlation between the binding activities measured using $\left[{ }^{3} \mathrm{H}\right] \alpha$-BGTX and $\left[{ }^{3} \mathrm{H}\right]$ imidacloprid has been reported. ${ }^{18)}$ However, the exact binding modes of these insecticides have not yet been fully elucidated.

There are two types of nAChRs which can be distinguished from each other by the response of mammalian brain tissue to the binding of $\alpha$-BGTX and $l$-nicotine. ${ }^{19)} \quad$ There are several reports dealing with the binding activity of chloronicotinyl insecticides to mammalian $\mathrm{nAChR}$ in terms of competition of $\left[{ }^{3} \mathrm{H}\right] l$-nicotine, ${ }^{11,20)}$ however, no information on binding assays using $\alpha$-BGTX has been found. In this study, we

\footnotetext{
* To whom correspondence should be addressed.
}

measured and compared the binding activities of chloronicotinyl compounds including imidacloprid, nitenpyram and acetamiprid to the $\alpha$-BGTX-sensitive $\mathrm{nAChR}$ prepared from Wister rat brain and housefly (Musca domestica L.) heads.

\section{MATERIALS AND METHODS}

\section{Test Chemicals}

The tested compounds are listed in Tables 1 and 2 . The following compounds were kindly provided by several companies: Compounds 1-19, Nihon Bayer Agrochem Co. (Ibaraki, Japan); compounds 20-31, Takeda Chemical Industries, Ltd. (Osaka, Japan); compound 32, Nippon Soda Co., Ltd. (Tokyo, Japan). $\quad \alpha$-BGTX was purchased from Sigma Chemical Co. (St. Louis, MO, USA). $\left[{ }^{125 I}\right] \alpha$-BGTX (74 $\mathrm{TBq} / \mathrm{mmol}$ ) was purchased from Amersham International (Buckinghamshire, UK). BCA protein assay reagents were purchased from Pierce (Rockford, IL, USA).

\section{2. $n A C h R$ Preparation}

\subsection{Rat brain}

Crude nAChR was prepared using rat brains by the conventional method. ${ }^{21)}$ Male Wister rats $(200 \mathrm{~g})$ were decapitated and the brains were quickly excised. The brains were homogenized $(10 \% \mathrm{wt} / \mathrm{vol})$ in saline containing $0.32 \mathrm{M}$ sucrose, $1 \mathrm{mM}$ EDTA, $0.1 \mathrm{mM}$ phenylmethylsulfonyl fluoride, and $0.1 \%$ (wt/vol) sodium azide. The homogenates were then centrifuged at $1000 \times g$ for $10 \mathrm{~min}$, and the supernatant was decanted and retained on ice. The pellet was suspended in $0.32 \mathrm{M}$ sucrose $(5 \mathrm{ml} / \mathrm{g}$ original wet weight $)$ and centrifuged at $1000 \times g$ for $10 \mathrm{~min}$. The combined supernatants were centrifuged at $12,000 \times g$ for $30 \mathrm{~min}$ to give a pellet which was resuspended in binding assay buffer $(\mathrm{pH} 7.4)$ containing $50 \mathrm{mM}$ potassium phosphate and protease inhibitors as described above $(2.5 \mathrm{ml} / \mathrm{g}$ of original wet weight of the rat brain). The protein concentration was determined by $\mathrm{BCA}$ protein assay reagents using BSA as a standard.

\subsection{Housefly heads}

A housefly head membrane fraction was prepared according to our previously described method. ${ }^{22}$

\section{Binding Assays}

Binding assays were done according to the method previously described. ${ }^{22)}$ Aliquots of rat-nAChR preparations (ca. $5 \mu \mathrm{g}$ protein) were incubated with $\left[{ }^{125} \mathrm{I}\right] \alpha$-BGTX $(0.5 \mathrm{nM})$ at $25^{\circ} \mathrm{C}$ for $60 \mathrm{~min}$ in a microplate. Similar assays were done for housefly-nAChR preparations (ca. $250 \mu \mathrm{g}$ protein) by incubating with test chemicals and $\left[{ }^{125} \mathrm{I}\right] \alpha$-BGTX (0.2 nM). Test chemicals were used at appropriate concentrations (ca. $\left.1 \times 10^{-2}-10^{-9} \mathrm{M}\right)$ in the corresponding binding assay buffer $(200 \mu 1)$. The reaction was terminated by rapid filtration through a Unifilter GF/B (Packard Instrument Co., Meriden, 
Table 1 Binding activities of imidacloprid and related compounds.

\begin{tabular}{|c|c|c|c|c|c|c|}
\hline \multirow{2}{*}{ No. } & \multicolumn{4}{|c|}{ Substituents } & \multicolumn{2}{|c|}{$\log \left(1 / K_{1}\right)$} \\
\hline & $X$ & $\mathrm{Y}$ & $\mathrm{Z}$ & $\mathrm{n}$ & Rat & Housefly $^{a}$ \\
\hline 1 & 3-Pyridylmethyl & $\mathrm{CHNO}_{2}$ & NH & 2 & 3.47 & 7.30 \\
\hline 2 & 6-Cl-3-pyridylmethyl & $\mathrm{CHNO}_{2}$ & NH & 2 & 4.15 & 7.49 \\
\hline 3 & 6-Me-3-pyridylmethyl & $\mathrm{CHNO}_{2}$ & NH & 2 & 3.07 & 6.72 \\
\hline 4 & 6-Cl-3-pyridyl & $\mathrm{CHNO}_{2}$ & NH & 2 & $<2.00$ & 4.47 \\
\hline 5 & 2-(6-Cl-3-pyridyl)ethyl & $\mathrm{CHNO}_{2}$ & NH & 2 & 3.25 & 4.71 \\
\hline 6 & 2-Pyridylmethyl & $\mathrm{CHNO}_{2}$ & NH & 2 & $<2.00$ & 4.84 \\
\hline 7 & 4-Pyridylmethyl & $\mathrm{CHNO}_{2}$ & NH & 2 & $<2.00$ & 3.14 \\
\hline 8 & Benzyl & $\mathrm{CHNO}_{2}$ & NH & 2 & $<2.00$ & 5.49 \\
\hline 9 & 4-Cl-benzyl & $\mathrm{CHNO}_{2}$ & NH & 2 & 3.08 & 5.30 \\
\hline 10 & 5-(2-Cl-thiazolyl)methyl & $\mathrm{CHNO}_{2}$ & NH & 2 & 4.24 & 6.97 \\
\hline 11 & 3-Pyridylmethyl & $\mathrm{NNO}_{2}$ & NH & 2 & $<2.00$ & 5.35 \\
\hline $12^{b}$ & 6-Cl-3-pyridylmethyl & $\mathrm{NNO}_{2}$ & NH & 2 & 4.08 & 6.00 \\
\hline 13 & 6-Cl-3-pyridylmethyl & $\mathrm{NNO}_{2}$ & $\mathrm{NMe}$ & 2 & 2.42 & 3.83 \\
\hline 14 & 6-Cl-3-pyridylmethyl & $\mathrm{NCN}$ & $\mathrm{NH}$ & 2 & $<2.00$ & 5.09 \\
\hline 15 & 6-Cl-3-pyridylmethyl & $\mathrm{CHCN}$ & NH & 2 & 2.49 & 5.11 \\
\hline 16 & 6-Cl-3-pyridylmethyl & $\mathrm{CHNO}_{2}$ & $\mathrm{CH}_{2}$ & 2 & 3.00 & 7.11 \\
\hline 17 & 6-Cl-3-pyridylmethyl & $\mathrm{CHNO}_{2}$ & $\mathrm{O}$ & 2 & 2.91 & 6.40 \\
\hline 18 & 6-Cl-3-pyridylmethyl & $\mathrm{CHNO}_{2}$ & $\mathrm{~S}$ & 2 & 2.92 & 7.00 \\
\hline 19 & 6-Cl-3-pyridylmethyl & $\mathrm{CHNO}_{2}$ & NH & 3 & 3.02 & 7.70 \\
\hline
\end{tabular}

${ }^{a}$ Taken from ref $22 .{ }^{b}$ Imidacloprid.

Table 2 Binding activities of nitenpyram and related compounds.

\begin{tabular}{|c|c|c|c|c|c|}
\hline \multirow{2}{*}{ No. } & \multicolumn{3}{|c|}{ Substituents } & \multicolumn{2}{|c|}{$\log \left(1 / K_{\mathrm{i}}\right)$} \\
\hline & $\mathrm{R}_{1}$ & $\mathrm{Y}$ & $\mathrm{R}_{2}$ & Rat & Housefly \\
\hline 20 & $\mathrm{H}$ & $\mathrm{CHNO}_{2}$ & $\mathrm{NH}_{2}$ & 2.42 & 3.71 \\
\hline 21 & $\mathrm{H}$ & $\mathrm{CHNO}_{2}$ & $\mathrm{NHN}\left(\mathrm{CH}_{3}\right)_{2}$ & $<2.00$ & 3.57 \\
\hline 22 & $\mathrm{Me}$ & $\mathrm{CHNO}_{2}$ & NHMe & 2.75 & 5.48 \\
\hline 23 & $\mathrm{Me}$ & $\mathrm{CHNO}_{2}$ & NHEt & $<2.00$ & 3.39 \\
\hline $24^{a}$ & Et & $\mathrm{CHNO}_{2}$ & $\mathrm{NHMe}$ & $<2.00$ & 5.17 \\
\hline 25 & Et & $\mathrm{CHNO}_{2}$ & NHEt & $<2.00$ & 3.46 \\
\hline 26 & Et & $\mathrm{CHNO}_{2}$ & $\mathrm{~N}\left(\mathrm{CH}_{2} \mathrm{CH}_{3}\right)_{2}$ & 2.45 & 3.27 \\
\hline 27 & Et & $\mathrm{CHNO}_{2}$ & NH(cyclopropyl) & 2.45 & 3.62 \\
\hline 28 & Et & $\mathrm{CHNO}_{2}$ & & $<2.00$ & 3.24 \\
\hline 29 & $\mathrm{CH}_{2} \mathrm{CH}_{2} \mathrm{~F}$ & $\mathrm{CHNO}_{2}$ & $\mathrm{NH}_{2}$ & 2.85 & 6.24 \\
\hline 30 & $\operatorname{Pr}$ & $\mathrm{CHNO}_{2}$ & $\mathrm{NH}_{2}$ & 3.99 & 5.96 \\
\hline 31 & $i-\operatorname{Pr}$ & $\mathrm{CHNO}_{2}$ & NHMe & 2.97 & 4.14 \\
\hline $32^{b}$ & $\mathrm{Me}$ & NCN & $\mathrm{Me}$ & 2.75 & 5.31 \\
\hline
\end{tabular}

${ }^{a}$ Nitenpyram. ${ }^{b}$ Acetamiprid.

CT, USA) that had been treated with $0.1 \%$ polyethylenimine to prevent the nonspecific binding of $\left[{ }^{125} I\right] \alpha$-BGTX to the filter. ${ }^{23)}$ The filters were rinsed three times with the binding buffer, followed by methanol, and then dried. Total radioactivity captured in the filter was measured as counts per minute (cpm) using a Topcount (Packard) instrument, after addition of Microscinti-O (30 $\mu \mathrm{l}$; Packard). Specific binding was defined as the difference in radioactivities measured in the absence $(10,000-15,000 \mathrm{cpm})$ and presence $(2000-3000 \mathrm{cpm})$ of $10 \mu \mathrm{M}$ unlabelled $\alpha$-BGTX. The saturation curve for the 
nAChRs was obtained by using only $\left[{ }^{125} \mathrm{I}\right] \alpha$-BGTX at various concentrations. All tests were done in triplicate, and the mean values of the radioactivity were used for further calculations.

\section{Data Calculations}

The molar concentrations required for $50 \%$ inhibition of the specific binding of $\left[{ }^{125} \mathrm{I}\right] \alpha$-BGTX $\left(\mathrm{IC}_{50}\right)$ were determined by nonlinear regression analysis using PRISM (Graphpad Software Inc., San Diego, CA, USA). The binding activity of test chemicals was evaluated by calculating $K_{1}$ using the following equation: ${ }^{24)}$

$$
K_{\mathrm{i}}=\mathrm{IC}_{50} /\left(1+[\mathrm{L}] / K_{\mathrm{d}}\right),
$$

where [L] is the concentration of the radiolabelled ligand and $K_{\mathrm{d}}$ is the dissociation constant. PRISM was used to determine $K_{\mathrm{d}}$ values for rat $(0.69 \mathrm{nM})$ and housefly preparations $(0.058 \mathrm{nM})$ through nonlinear regression analysis of $\left[{ }^{125} \mathrm{I}\right]$ $\alpha$-BGTX saturation curves. The $\log \left(1 / K_{1}\right)$ values, which are listed in Tables 1 and 2, were taken as the index of the binding activity. The binding assay was repeated for several compounds to assess the reproducibility of the $\log \left(1 / K_{1}\right)$ within an error of \pm 0.3 .

\section{RESULTS AND DISCUSSION}

We were able to determine $\log \left(1 / K_{\mathrm{i}}\right)$ values with the housefly preparation for all of the compounds tested, whereas $\log \left(1 / K_{\mathrm{i}}\right)$ values were determinable for only 21 compounds with the rat preparation (Tables 1 and 2). The $\log \left(1 / K_{\mathrm{i}}\right)$ values for housefly preparation varied from 3.1 to 7.7 , and the values for rat preparation ranged from 2.4 to 4.3 or lower. All of the tested compounds showed higher binding activity to housefly $\mathrm{nAChR}$ than to rat brain $\mathrm{nAChR}$. This result demonstrates that the binding to $\alpha$-BGTX-sensitive insect$\mathrm{nAChR}$ is dependent much more than the mammal-nAChR upon chemical structure of this class of compounds. The present results with the rat $\mathrm{nAChR}$ were in agreement with the binding activity of imidacloprid (determined using $\left[{ }^{3} \mathrm{H}\right] l$ nicotine with rat $\mathrm{nAChR}{ }^{11)}$ and of compounds 1-19 (using $\left[{ }^{3} \mathrm{H}\right] l$-nicotine with mouse $\left.\mathrm{nAChR}^{20)}\right)$. Consequently, the high selective toxicity of this class of compounds to insects might be due to their high binding affinity, representatively demonstrated with housefly $\mathrm{nAChR}$, and low binding affinity to rat $\mathrm{nAChR}$.

In the rat-nAChR binding assay, imidacloprid (12) was more active than nitenpyram (24) and acetamiprid (32) (Tables 1 and 2). This is consistent with the rating of their toxicity to mice and rats. ${ }^{4}$ Nitenpyram (24) showed the lowest toxicity to mice and rats. ${ }^{4)}$ Its binding activity towards rat $\mathrm{nAChR}$ was not determinable in terms of $\log (1 /$ $\left.K_{1}\right)$. Cyclic compounds 2 and 10, and the acyclic compound 30 showed similar binding activity to imidacloprid (12) in rat brain preparation. Because of the small variations in the activity toward the rat $\mathrm{nAChR}$, it was difficult to quantitatively draw any substructures required for binding.
Recently, insect nAChR was purified by affinity chromatography using an imidacloprid derivative. ${ }^{25)}$ The structure of Torpedo $\mathrm{nAChR}$ has been shown by electron microscopy ${ }^{26)}$ and $\mathrm{NMR}^{27)}$ techniques. Both of these studies on $\mathrm{nAChR}$, as well as our structural analyses of the insecticides, aid in revealing the mode of selectivity and structural requirements necessary for a high affinity to the insect nAChR. We predicted the binding mode of imidacloprid and its cyclic derivatives by a technique of three-dimensional quantitative structure analysis using the binding data determined with the housefly nAChR. ${ }^{22)}$ Analyses are currently under way for acyclic chloronicotinyl insecticides.

\section{ACKNOWLEDGMENTS}

We are thankful to Mr. Craig Wheelock for the careful reviewing of the manuscript. We are grateful to Dr. Isao Ueyama of the Nihon Bayer Agrochem Co., Dr. Hideki Uneme of the Takeda Chemical Ind. and Dr. Akira Nakayama of Nippon Soda Co. for providing some of the test compounds. A part of this study was performed in the RI Center of Kyoto University.

\section{REFERENCES}

1) W. Leicht: Pflanzenschutz-Nachr. Bayer 49, 71 (1996)

2) A. S. Moffat: Science 261, 550 (1993)

3) S. Kagabu: Rev. Toxicol. 1, 75 (1997)

4) I. Yamamoto: Agrochemicals Japan 68, 14 (1996)

5) M. Matsuda \& H. Takahashi: Agrochemicals Japan 68, 20 (1996)

6) Y. Kashiwada: Agrochemicals Japan 68, 18 (1996)

7) D. Bai, S. C. R. Lummis, W. Leicht, H. Breer \& D. B. Sattelle: Pestic. Sci. 33, 197 (1991)

8) S. Sone, K. Nagata, S. Tsuboi \& T. Shono: J. Pesticide Sci. 19, 69 (1994)

9) M. Tomizawa \& I. Yamamoto: J. Pesticide Sci. 17, 231 (1992)

10) M. Tomizawa \& I. Yamamoto: J. Pesticide Sci. 18, 91 (1993)

11) I. Yamamoto, G. Yabuta, M. Tomizawa, T. Saito, T. Miyamoto \& S. Kagabu: J. Pesticide Sci. 20, 33 (1995)

12) B. Latli \& J. E. Casida: J. Labelled Compd. Radiopharmacol. 31, 609 (1992)

13) B. Latli, C. Than, H. Morimoto, P. G. Williams \& J. E. Casida: J. Labelled Compd. Radiopharm. 38, 971 (1996)

14) M.-Y. Liu, J. Lanford \& J. E. Casida: Pestic. Biochem. Physiol. 46, 200 (1993)

15) M.-Y. Liu \& J. E. Casida: Pestic. Biochem. Phyisol. 46, 40 (1993)

16) R. J. Lind, M. S. Clough, S. E. Reynolds \& F. G. P. Earley: Pestic. Biochem. Physiol. 62, 3 (1998)

17) M.-Y. Liu, B. Latli \& J. E. Casida: Pestic. Biochem. Physiol. 52, 170 (1995)

18) M.-Y. Liu, B. Latli \& J. E. Casida: Pestic. Biochem. Biophys. 50, 171 (1994)

19) E. X. Albuquerque, E. F. Pereira, N. G. Castro, M. Alkondon, S. Reinhardt, H. Schroder \& A. Maelicke: Ann. NY Acad. Sci. 757, 48 (1995)

20) S. L. Chao \& J. E. Casida: Pestic. Biochem: Physiol. 58, 77 
(1997)

21) C. Rapier, G. G. Lunt \& S. Wonnacott: J. Neurochem. 54, 937 (1990)

22) A. Okazawa, M. Akamatsu, A. Ohoka, H. Nishiwaki, W.-J. Cho, Y. Nakagawa, K. Nishimura \& T. Ueno: Pestic. Sci. 54, 134 (1998)

23) R. F. Bruns, K. Lawson-Wendling \& T. A. Pugsley: Anal. Biochem. 132, 74 (1983)

24) Y.-C. Cheng \& W. H. Prusoff: Biochem. Pharmacol. 22, 3099 (1973)

25) M. Tomizawa, B. Latli \& J. E. Casida: J. Neurochem. 67, 1669 (1996)

26) N. Unwin: J. Mol. Biol. 229, 1101 (1993)

27) A. A. Lugovskoy, I. V. Maslennikov, Y. N. Utkin, V. I. Tsetlin, J. B. Cohen \& A. S. Arseniev: Eur. J. Biochem. 255, 455 (1998)
要 約

ラットとイエパエのニコチン性アセチルコリン受容体 に対するクロロニコチニル殺蛳の結合活性の比較

岡澤敦司, 中川好秋, 赤松美紀, 上野民夫, 西村勁一郎 イミダクロプリド，アセタミプリド，ニテンピラムおよびそ れらの類縁化合物のラットとイエバエのニコチン性アセチルコ リン受容体に対する結合活性を，[125I] $\alpha$-bungarotoxin を用い て測定した。用いた濃度において，すべての化合物がイエバ工 の受容体に対する結合活性を有したが，ラットの受容体に对し ては 21 化合物しか活性を示さなかった. また，ラットの受容体 に対する活性值はイエバエの受容体に対する活性值の $1 / 10$ 〜1/10,000であった．なお，これらの殺虫剤のラットに対する 毒性の強さは, ラットの受容体に対する結合活性值の高さに対 応していた。本実験の結果より, クロロニコチニル殺虫剤の選 択性は，その受容体への結合活性の差によって説明できること が示された。 